\title{
Oral symptoms and oral health in patients with chronic kidney disease
}

\author{
Maria Auxiliadora Gomes do NASCIMENTO' \\ (i) ORCID iD 0000-0002-3601-387X \\ Maria Sueli Marques SOARES² \\ (iD) ORCID iD 0000-0003-0712-8456 \\ Eduardo CHIMENOS KÜSTNER ${ }^{3}$ \\ (i) ORCID ID 0000-0002-0728-1808 \\ Dasaiev Monteiro DUTRA ${ }^{1}$ \\ (D) ORCID iD 0000-0001-6829-4832 \\ Raquel Lopes CAVALCANTI ${ }^{2}$ \\ (iD) ORCID iD 0000-0002-4615-9258
}

Sintomas bucais e saúde bucal em pacientes com doença renal crônica

\section{ABSTRACT}

\section{Objective}

Chronic kidney disease is characterized by progressive and irreversible loss of kidney function. The impact of this disease on oral health also presents controversial results. The aim of the study was to determine oral health conditions and oral symptoms of patients with Chronic kidney disease undergoing hemodialysis.

\section{Methods}

A cross-sectional study on a population with chronic renal failure was performed. Anamnesis and oral examination, decayed, miss and filled teeth (DMFT) index, community periodontal index, simplified oral hygiene index (OHI-S) and gingival index were conducted. Data were processed using SPSS v.S. 20.0 using descriptive statistics and Fischer's exact test and ANOVA test ( $p<0.05)$.

\section{Results}

$64.9 \%$ of all the individuals were male. The mean age was $50.7 \pm 14.8$ years. $82.4 \%$ had symptoms oral while $44.6 \%$ had xerostomia and $31.1 \%$ dysgeusia. The mean DMFT was 20.49+8.68, the GI was low in $78.4 \%$ and the OHI-S was satisfactory in $73 \%$; according to the community periodontal index, the presence of dental calculus occurred in $52.7 \%$, periodontal pockets $41.9 \%$ and gingivitis $2.7 \%$. There was a statistically significant association between xerostomia $(p=0.017)$ and number of drugs consumed and between dysgeusia and OHI-S ( $p=0.011)$.

\section{Conclusion}

The results suggest that oral symptoms such as dry mouth and dysgeusia, are common in Chronic kidney disease patients undergoing hemodialysis. Dental calculus and periodontal disease in Chronic kidney disease may be severe even if low amount of biofilm is present. It is important that dentists know the most prevalent oral symptoms in the patient with Chronic kidney disease, as well as knowing that the periodontal condition of this patient should be carefully supervised.

Indexing terms: Chronic kidney disease. Hemodialysis. Oral Health. Xerostomia.

\section{RESUMO}

Objetivo

Avaliar as condições dental e periodontal e sintomas bucais em pacientes com com doença renal crônica em hemodiálise.

\section{Métodos}

Realizou-se estudo transversal, com amostra de 74 indivíduos. Foi realizada anamnese e registrados dados sobre sintomas bucais de xerostomia, ardor bucal e disgeusia. Foram aplicados os índices: CPO-D (dentes permanentes cariados, perdidos e obturados), CPI (índice periodontal comunitário), IHO-S (índice de higiene oral simplificado) e ISG (índice de sangramento gengival). Realizou-se análise descritiva dos dados e foram aplicados testes Teste Exato de Fischer e ANOVA, considerando $p<0,05$.

\section{Resultados}

Em $64,9 \%$ os indivíduos eram do sexo masculino. A média de idade foi $50,7 \pm 14,8$ anos. Os sintomas bucais ocorreram em $82,4 \%$ dos indivíduos, sendo $44,6 \%$ xerostomia e $31,1 \%$ disgeusias. O CPO-D médio foi 20,4 48,6 ; o ISG foi baixo em 78,4\% e o IHO-S foi satisfatório em $73 \%$; no CPI, cálculo dentário ocorreu em $61 \%$ sendo mais prevalente, bolsa periodontal ocorreu em $32,8 \%$ dos casos e gengivite em 3,1\%.

\section{Conclusão}

Indivíduo com com doença renal crônica pode apresentar elevada quantidade de cálculo dental, mesmo quando há baixa quantidade de biofilme dental. A ocorrência de sintomas bucais é um achado comum na doença renal crônica.

Termos de indexação: Insuficiência renal crônica. Diálise renal. Saúde bucal. Xerostomia.

\footnotetext{
${ }^{1}$ Centro Universitário de João Pessoa. Rod. BR-230, KM 22, s/n., 58053-000, Água Fria, João Pessoa, PB, Brasil. Correspondência para / Correspondence to: MAG NASCIMENTO. E-mail: <dodora.gomes@hotmail.com>.

${ }^{2}$ Universidade Federal da Paraíba, Departamento de Clínica e Odontologia Social. João Pessoa, PB, Brasil.

${ }^{3}$ Universidade de Barcelona, Faculdade de Odontologia, Departamento de Odontoestomatologia. Barcelona, Espanha.

$\boldsymbol{\nabla} \mathbf{v}$

Como citar este artigo / How to cite this article

Nascimento MAG, Soares MSM, Chimenos-Küstner EC, Dutra DM, Cavalcanti RL. Oral symptoms and oral health in patients with chronic kidney disease. RGO, Rev Gaúch Odontol. 2018;66(2):00-00. http://dx.doi.org/10.1590/1981-863720180002000093436
} 


\section{INTRODUCTION}

Chronic kidney disease (CKD) is characterized by hydroelectrolytic, metabolic and immune disorders due to progressive and irreversible renal function loss [1]. There are no specific oral signs or symptoms in CKD patients however several oral manifestations secondary to the disease are observed, and poor oral health condition may imply more infections and maintenance of systemic inflammation [2]. Nevertheless CKD patients' oral health has not been receiving the required attention and care $[3,4]$. The main oral manisfestations in patients with CKD include periodontal disease, fast formation of dental calculus, dysgeusia, xerostomia, hyposalivation and $\mathrm{pH}$ salivary alteration $[4,5]$. Although controversial these alterations, which occur during CKD evolution, may be related to drug therapy, fluid consumption restriction, immunosuppression, renal osteodystrophy and bone loss $[1,4]$.

Rate changes in stimulated and salivary flow at rest, a higher prevalence of xerostomia [6] and periodontal disease have been observed in CKD patients undergoing hemodialysis, however, the influence of oral hygiene and systemic factors in the formation of dental calculus is controversial $[3,5]$. The present study aimed at assesseing the dental, periodontal and presence of oral symptoms in a group of patients with CKD undergoing hemodialysis.

\section{METHODS}

\section{Study sample}

A total of 179 chronic kidney disease individuals attended at a hemodialysis center in the city of João Pessoa / State of Paraíba (PB), of whom 79 accepted to participate in the study. The final sample consisted of 74 volunteer participants of both sexes, presenting chronic kidney disease undergoing hemodialysis and whose physical condition allowed oral examination. The exclusion criteria consisted of patients who underwent peritoneal dialysis, those who did not have the physical conditions for oral exam, those who did not agree to participate in the study, and those who died (3 participants) or who had received a renal transplantation during the study (2 participants).

The study was approved by the Committee of Ethics in Research in Human Beings of the Health Sciences Center / UFPB, CAAE nº 09935412.9.0000.5188.
All patients in the sample were submitted to anamnesis and oral examination performed by a single dentist. The presence of oral symptoms such as: xerostomia, dysgeusia and oral burning were recorded once the question about these symptoms was answered affirmatively.

DMFT (Decayed/Missing/Filled Teeth), index was applied in order to assess the dental condition, as follows: for the periodontal condition, the CPI (Community Periodontal Index) and GI (Gingival Index) indices. The degree of oral hygiene was evaluated by the OHI-S (Simplified Oral Hygiene Index), using the scores: 0 to 1 (satisfactory oral hygiene); 1.1 to 2 (regular oral hygiene) and 2.1 to 3 (poor oral hygiene).

The data were processed in a statistical program SPSS (Statistical Package for Social Science) in version 20.0 (SPSS Inc., Chicago, IL, USA), and a descriptive analysis was performed and Fisher's exact test and ANOVA were used, considering significant values of $p$ $<0.05$

\section{RESULTS}

Among the 74 individuals in the sample, $64.9 \%$ were male and age ranged from 21 to 86 years, with an average of $50.7 \pm 14.8$ years. The mean time for the nephropathy patients was $64.8 \pm 64.8$ months and undergoing hemodialysis was $60.1 \pm 62.3$ months. Hypertension and diabetes mellitus were the most frequent systemic diseases in the study group, and the most commonly consumed drugs were antianemics, recalcificants, antihypertensives and vitamins (Table 1). All 20 subjects presented type 2 diabetes mellitus. Only 05 used oral hypoglycemic drugs, the others managed their diabetes with diet and / or physical exercises.

In the sample, $82.4 \%$ (61) of the individuals complained of some oral symptoms, among these, $44.6 \%$ (33) reported xerostomia, 31.1\% (23) presented dysgeusia and $6.7 \%$ (5) felt oral burning, with a higher occurrence of bitter taste, $69.5 \%$ (16), followed by metallic taste sensation $17.4 \%$ (4) and sweet taste alteration 13\% (3). Xerostomia was statistically significant with the number of drugs consumed ( $p=0.017$ ) and dysgeusia statistically significant associated with OHI-S ( $p=0.011)$.

The mean DMFT was $20.49+8.68$ and total edentulism occurred in $12.2 \%$ (9) of the individuals. Regarding the periodontal condition, it was observed that the majority of the individuals presented satisfactory oral 
hygiene index and low gingival bleeding, however a high prevalence of dental calculus formation was observed. In 39 patitents (52.7\%) (39) dental calculus was observed and $41.9 \%$ (31) presented periodontal pocket and only $2.7 \%$ (2) gingivitis. It is worth mentioning that among the 54 patients who had satisfactory oral hygiene, the majority (34) presented high dental calculus formation, which shows that those patients presenting low amount of dental biofilm presented dental calculus. At the same time, the study has shown that out of the 14 patients with poor oral hygiene 12 (85.7\%) presented periodontal pocket $\geq 6 \mathrm{~mm}$ (Table 2). The results in Table 3 show a statistically significant association between periodontal indices and dental conditions, as well as between dygeusia and $\mathrm{OHI}-\mathrm{S}$.

Table 1. Demographic and disease characteristics in the sample studied.

\begin{tabular}{|c|c|c|c|}
\hline Sample characteristics & & Mean \pm DV & $n(\%)$ \\
\hline Age( years) & & $50.7 \pm 14.8$ & \\
\hline \multirow[t]{2}{*}{ Sex } & Male & & $48(64.9 \%)$ \\
\hline & Female & & $26(35.1 \%)$ \\
\hline Morbidities & & & $59(79.7 \%)$ \\
\hline Hypertension & & & $49(66.2 \%)$ \\
\hline & & $139.6 \pm 107$ & $20(27 \%)$ \\
\hline Diabetes & & & $12(16.2 \%)$ \\
\hline \multicolumn{4}{|l|}{ Cardiopathies } \\
\hline $\begin{array}{l}\text { Mean time of } \\
\text { comorbidity (months) }\end{array}$ & & $139.6 \pm 107$ & \\
\hline $\begin{array}{l}\text { Mean time of } \\
\text { nephropathy (months) }\end{array}$ & & $64.8 \pm 64.8$ & \\
\hline $\begin{array}{l}\text { Mean time of } \\
\text { hemodialysis (months) }\end{array}$ & & $60.1 \pm 62.3$ & \\
\hline \multirow[t]{2}{*}{$\begin{array}{l}\text { Average fluid } \\
\text { consumption }\end{array}$} & & $816.8 \pm 69.3$ & \\
\hline & & & $74(100 \%)$ \\
\hline \multicolumn{4}{|l|}{ Comsumed drogs } \\
\hline & & & $5(6.8 \%)$ \\
\hline \multicolumn{4}{|l|}{ Hypoglycemic agents } \\
\hline & & & $27(36 \%)$ \\
\hline \multicolumn{4}{|l|}{ Antihypertensies } \\
\hline & & & $10(13 \%)$ \\
\hline \multicolumn{4}{|r|}{+2} \\
\hline \multicolumn{4}{|l|}{ Recalcificants } \\
\hline Antianemics & & & $13(17 \%)$ \\
\hline Others & & & \\
\hline
\end{tabular}

Source: Research data, João Pessoa, 2014. SD = standard deviation.
Table 2. Contingency analysis of $\mathrm{CPI}$ and $\mathrm{OHI}-\mathrm{S}$.

\begin{tabular}{lcccccc}
\hline & \multicolumn{1}{c}{ CPI } & & & \\
\hline OHI-S & Healthy & Bleeding Calculus & $\begin{array}{c}4 \mathrm{a} \\
5 \mathrm{~mm} \\
\text { Pocket }\end{array}$ & $\begin{array}{c}\text { de } \\
6 \mathrm{~mm} \\
\text { or } \\
\text { more } \\
\text { pocket }\end{array}$ & Total \\
\hline Satisfactory $\mathrm{OH}$ & 2 & 2 & 34 & 14 & 2 & 54 \\
Regular $\mathrm{OH}$ & 0 & 0 & 4 & 2 & 0 & 6 \\
Poor $\mathrm{OH}$ & 0 & 0 & 1 & 1 & 12 & 14 \\
Total & 2 & 2 & 39 & 17 & 14 & 74 \\
\hline
\end{tabular}

Source: Research data, UFPB, 2014. OH: oral hygiene.

Table 3. Distribution of the variables with statistically significant association.

\begin{tabular}{cc}
\hline Variables & Values of $\mathrm{p}$ \\
\hline CPI x OHI-S & $0.0000^{*}$ \\
CPI x GI & $0.0000^{*}$ \\
CPI x CPO-D & $0.0166^{*}$ \\
GI x CPO-D & $0.0020^{*}$ \\
OHI-S x GI & $0.0000^{*}$ \\
OHI-S x CPO-D & $0.0004^{*}$ \\
OHI-S x Dygeusia & $0.0146^{*}$ \\
\hline
\end{tabular}

Source: Research data, UFPB, 2014.

Note: (1) Fisher's exact test; (2) ANOVA test; * $P<0.05$ : significant.

\section{DISCUSSION}

Previous studies suggest that chronic kidney disease patients undergoing hemodialysis are more prone to worse oral health conditions than the general population $[3,4,7]$. Co-morbidities and systemic diseases associated with CKD can cause changes in the periodontium leading to exacerbation of the inflammatory response in the gingival tissue and to degenerative gingiva [3]. Besides that, uremia causes lymphocyte response suppression, granulocyte dysfunction, and cell-mediated immunity suppression. CKD patient undergoing hemodialysis may present a decrease in leukocyte production $[8,9]$, triggering severe periodontal disease predisposition. In the present study, $97.3 \%$ of the patients evaluated presented periodontal disease, corroborating other studies $[5,10]$.

High prevalence of dental calculus in CKD patients seems to be a common finding $[2,5]$, however, the literature is controversial concerning the relationship among the amount of biofilm, gingivitis and the amount of dental calculus. CKD does not seem to ben an additional risk factor for severe destruction of the periodontium, resulting from the amount of dental biofilm [9], however, some authors report no association between biofilm and dental calculus in CKD patients [5,11], and, suggest the influence of other factors on the formation of dental 
calculus in those patients. Considering that the biofilm deposition precedes the dental calculus formation, the lack of association between the presence of biofilm and calculus in these studies reinforces the theory that systemic CKD factors may be related to the calculus formation. This statement highlights the findings of the present study which demonstrates that even among those individuals with low biofilm index, high percentage of dental calculus was found.

It is believed that the CKD patient undergoing hemodialysis presents faster dental calculus formation due to the ingestion of high amount of calcium-based phosphate chelator, secondary hyperparathyroidism, oral hygiene deficiency, and decreased salivary clerancer [12]. In the present study the individuals presented several factors that could interfere in the formation of the dental calculus such as low amount of liquids and a great percentage of calcium supplement ingestión.

It is important to understand other factors involved in the formation of dental calculus when it comes to CKD such as changes in salivary composition with decreased magnesium level and increase in the level of urea and phosphorus which can lead to calciumphosphorous precipitation and calcium oxalate leading to dental calculus formation $[13,14]$. Low amount of inhibitors of calcification in the saliva of individuals undergoing hemodialysis, as mentioned in a clinical study [15]. can be considered.

Calcification inhibitors are compounds, present in most body fluids and prevent body spontaneous mineralization, even in calcium phosphate supersaturation. Calcification inhibitory substances, when in CKD patients presenting saliva low concentration can favor or accelerate the dental biofilm calcification. Further studies are necessary in order to evaluate the presence and role of such components in the saliva of CKD patients, since these components may be involved in the accelerated dental calculus formation.

The sample of the present study showed individuals with low index of gingival bleeding, which corroborates the results of other studies in patients undergoing hemodialysis when compared to the control group $[5,9,11,14]$, however diverge from another study where gingival bleeding is a frequent finding $[3,16]$. Anemia interfering with the inflammatory response and masking gingival inflammation is a possible explanation for the low degree of gingival bleeding in patients with $\mathrm{CKD}^{17}$. In the present study all individuals were under antianemic medication.
In the present study, an interesting fact observed was that the majority of individuals with satisfactory $\mathrm{OHI}-\mathrm{S}$ presented a high percentage of dental calculus and periodontal pocket. Significant association was observed between OHI-S and $\mathrm{CPI}$ and between $\mathrm{OHI}-\mathrm{S}$ and $\mathrm{GI}$, differently from several studies involving CKD patients and control groups, where no significant difference was observed between periodontal indices and pocket depth [3-5]. Poor association was observed between the biofilm index and the presence of periodontal in CKD patients undergoing hemodialysis [3]. This finding may be related to the immunomodulating effect of renal disease [4], although it has been shown that even under immunosuppressive conditions, the periodontal tissues of the individual on hemodialysis present a similar reaction to that of healthy individuals [4].

In the present study, mean DMFT was high which shows a significant correlation with patient's age, in agreement with the scientific literature [18].

Oral symptoms such as xerostomia, dygeusia, halitosis and burning of the mouth $[12,19]$ are frequently reported by the CKD patient. In the present study, the prevalence of dysgeusia was high, corroborating with the literature $[6,11,12,20-22]$.

Bitter taste was more frequent, diverge data from that observed in other studies which have reported dysgeusia with metallic taste predominance in CKD patients $[1,6,19,23]$. Dysgeusia in the renal patient is related to the higher concentration of urea in saliva $[12,24]$, as well as hyposalivation $[1,6,19,23]$, qualitative and quantitative changes in saliva. In the present study, a statistically significant association between $\mathrm{OHI}-\mathrm{S}$ and dysguesia was demonstrated, showing the need for future studies on the role of biofilm and mouth symptoms in CKD patients.

Similar to the results of the present study several authors have stated that xerostomia is more frequent in patients undergoing hemodialysis than in healthy individuals $[1,6,20,21,23,25]$. Xerostomia in patients with CKD can be caused due to fluid intake restriction related to reduced renal capacity $[1,25]$.

In the present study, the average fluid intake was low $(816.89+694.26 \mathrm{ml} /$ day $)$ and a high percentage of individuals with xerostomia was observed, a similar finding in some studies $[6,8,12,20,21]$, however diferent from other authors' conclusions $[14,19,22]$. The divergence of results between studies may be due to the different characteristics of the samples, including the number and types of drugs consumed, mean age, reduction of 
salivary flow, average fluid consumption, among other characteristics of the individuals studied. It is essential to emphasize that a statistically significant association between xerostomia and the number of medications ( $p$-value $=0.017$ ) was observed. All of the patients were under medication, especially antihypertensives which lead to hyposalivation and are considered xerostomizing. Reduction of salivary flow after medication increase was previously reported in another study with patients with CKD [26]. On the other hand, it has been suggested that dry mouth sensation in patients with CKD is associated with bicarbonate decrease and calcium increase in saliva [21].

\section{CONCLUSION}

CKD patiens undergoing hemodialysis may present a high amount of dental calculus, even when low amount of dental biofilm is observed as well as high percentage of symptoms of oral discomfort. It is worth

\section{REFERENCES}

1. Proctor R, Kumar N, Stein A, Moles D, Porter S. Oral and dental aspects of chronic renal failure. J Dent Res. 2005; 84:199-208.

2. Kocyigit I, Yucel HE, Cakmak O, Dogruel F, Durukan DB, Korkar $\mathrm{H}$, et al. An ignored cause of inflammation in patients undergoing continuous ambulatory peritoneal dialysis: periodontal problems. Int Urol Nephrol. 2014; 46:2021-8. doi: 10.1007/s11255-014-0716-z

3. Castilho A, Mesa F, Liébana J, García-Martinez O, Ruiz S, García Valdecasas, et al. Periodontal and oral microbiological status of an adult population undergoing haemodialysis: a cross-sectional study. Oral Dis. 2007;13(2):198-doi: 205. 10.1111/j.16010825.2006.01267.x

4. Klassen JT, Krasko BM. The dental health status of dialysis patients. J Can Dent Assoc. 2002;68(1):34-8.

5. Martins C, Siqueira WL, Oliveira E, Nicolau J, Primo LG. Dental calculus formation in children and adolescents undergoing hemodialysis. Pediatr Nephrol. 2012 Oct;27(10):1961-6. doi: 10.1007/s00467-012-2194-9

6. Kao CH, Hsieh JF, Tsai SC, Ho YJ, Chang HR. Decreased salivary function in patients with end-stage renal disease requiring hemodialysis. Am J Kidney Dis. 2000;36(6):1110-1114. doi: 10.1053/ajkd.2000.19810

7. Tadakamadla J, Kumar S, Mamatha GP. Comparative evaluation of oral health status of chronic kidney disease (CKD) patients in various stages and healthy controls. Spec Care Dentist. 2014 May-Jun;34(3):122-6. doi: 10.1111/scd.12040

8. Gudapati A, Ahmed P, Rada R. Dental management of patients with renal failure. Gen Dent. 2002; 50(6):508-510. noting the importance of the dentist's role regarding the most prevalent oral symptoms in the patient with CKD, as well as to supervise the patients' periodontal conditions.

\section{Special thanks}

The authors would like to thank the National Research Institute (NRI) for the grant support and scientific initiation.

\section{Collaborators}

MAG NASCIMENTO e MSM SOARES were lyrics by conception and design; collecting, analyzing and interpreting data; writing and critical review manuscript. EC KÜSTNER was responsible for the conception and design; the data analysis and interpretation. DM DUTRA e RL CAVALCANTI were market by collecting data, writing and review manuscript.

9. Marakoglu I, Gursoy UK, Demirer S, Sezer H. Periodontal status of chronic renal failure patients receiving hemodialysis. Yonsei Med J. 2003;44(4)648-652. doi: 10.3349/ymj.2003.44.4.648

10. Kim YJ, de Moura LM, Caldas CP, Perozini C, Ruivo GF, Pallos D. Evaluation of periodontal condition and risk in patients with chronic kidney disease on hemodialysis. Einstein. 2017;15(2):173-177. doi: 10.1590/S1679-45082017A03867

11. Bots $\mathrm{CP}$, Poorterman $\mathrm{JH}$, Brand $\mathrm{HS}$, Kalsbeek $\mathrm{H}$, van Amerongen $B M$, Veerman EC, et al. The oral health status of dentate patients with chronic renal failure undergoing dialysis therapy. Oral Dis. 2006; 12(2):176-180. doi: 10.1111/j.1601-0825.2005.01183.x

12. Kaushik A, Reddy SS, Umesh L, Davi BKY, Santana N, Rakesh $\mathrm{N}$. Oral and salivary changes among renal patients undergoing hemodialysis: a cross-sectional study. Indian J Nephrol. 2013; 23(2):125-129. doi: 10.4103/0971-4065.109421

13. Davidovich E, Davidovits $M$, Peretz B, Shapira J, Aframian DJ. The correlation between dental calculus and disturbed mineral metabolism in paediatric patients with chronic kidney disease. Nephrol Dial Transplant. 2009;24:2439-2445. doi: 10.4103/0971-4065.109421

14. Martins C, Siqueira WL, Primo LSSG. Oral and salivary flow characteristics of a group of Brazilian children and adolescents with chonic renal failure. Pediatr Nephrol. 2008;23:619-624. doi: 10.1007/s00467-007-0718-5

15. Shroff RC, Shah V, Hiorns MP, Schoppet M, Hofbauer LC, Hawa $G$, et al. The circulating calcification inhibitors, fetuin-A and osteoprotegerin, but not Matrix Gla protein, are associated with vascular stiffness and calcification in children in dialysis. Nephrol Dial Transplant. 2008; 23(10):3263-3271. doi: 10.1093/ndt/ gfn226

16. Souza CRD, Libério SA, Guerra RNM, Monteiro S, Silveira EJD, 
Pereira ALA. Avaliação da condição periodontal de pacientes renais em hemodiálise. Rev Assoc Med Bras. 2005; 51:285-289.

17. Jaffer EC, Roberts GT, Chantle C, Carter JE. Dental findings in chronic renal failure. Br Dent. 1986;160(1):18-20.

18. Souza CM, Braosi AP, Luczyszyn SM, Casagrande RW, PecoitsFilho $R$, Riella $M C$, et al. Oral health in brazilian patients with chronic renal disease. Rev Méd Chile. 2008;136(6):741-746.

19. Dirschnabel AJ, Martins AS, Dantas SA, Ribas MO, Grégio AM, Alanis LR, et al. Clinical oral findings in dialysis and kidney patients. Quintessence Int. 2011; 42(2):127-133.

20. Honarmand M, Farchd-Mollashahi L, Nakhaee A, Sargolzaie F. Oral manifestation and salivary changes in renal patients undergoing hemodialysis. J Clin Exp Dent. 2017;9:e207-10.

21. Manley KJ. Saliva composition and upper gastrointestinal symptoms in chonic kidney disease. J Ren Care. 2014;40:172179.

22. Oytola EO, Owotade FJ, Agebelusi GA, Fatusi OA, Sanusi AA. Oral findings in chonic kidney disease: implications for management in developing countries. BMC. 2015;15:24-31.
23. Popovaska M, Spazovski G, Orovcanec N, Cekovska S, Simonceva M, Bexeti-Zendeli L, et al. Oral Findigs in End-Stage Renal Disease. Sec Med Sci. 2013; 34(3):85-91.

24. Postorino M, Catalano C, Martorano C, Cutrupi S, Marino C, Cozzupoli $P$, et al. Salivary and lacrimal secretion is reduced in patients with ESRD. Am J Kidney Dis. 2003; 42(4):722-728.

25. de la Rosa - García E, Mondragón-Padilla A, Aranda-Romo S, Bustamente-Ramírez MA. Oral mucosa symptoms, signs and lesions, in end stage renal disease and non-end stage renal disease diabetic patients. Med Oral Patol Oral Cir Bucal. 2006;11:E467-73.

26. Nylund KM, Meurman JH, Heikkinen AM, Furuholm JO, Ortiz F, Ruokonen HM. Oral health in patients with renal disease: a longitudinal study from predialysis to kidney transplantation. Clin Oral Invest. 2017; doi 10.1007/s00784-017-2118-y.

Received on: 24/5/2017

Final version resubmitted on: 16/11/2017

Approved on: 20/12/2017 